Терехова Валентина Владимировна

кандидат юридических наук, доцент, доцент кафедры финансового права Российского государственного гуманитарного университета

\section{ПРАВОВОЕ РЕГУЛИРОВАНИЕ ДЕЯТЕЛЬНОСТИ ОФШОРНЫХ БАНКОВ В НЕКОТОРЫХ ЮРИСДИКЦИЯХ}

\section{Аннотация:}

В статье представлен сравнительно-правовой анализ деятельности банковских кредитных организаций в разных юрисдикциях. Автор раскрывает некоторые аспекты правового регулирования функционирования офшорных банков в таких странах, как Панама, Швейцария и Монако. В частности, характеризуются контрольно-надзорные полномочия государства в отношении офшорных банков, обобщаются особенности налогообложения и лицензирования их деятельности. Кроме того, приводятся конкретные показатели по налогообложению изучаемых офшорных юрисдикций. Банковская деятельность рассматривается через налоговые правоотношения. Обозначаются различные точки зрения российских ученых по данному вопросу, в том числе указывается на их экономическую, а не юридическую направленность, что подтверждает актуальность и своевременность предпринятого исследования. Формулиру ется вывод о положении офшорных банков в Па наме, Швейцарии и Монако.

Ключевые слова:

офшор, банк, юрисдикция, надзор, налогообложение.
Terekhova Valentina Vladimirovna

PhD in Law, Associate Professor, Financial Law Department, Russian State University for the Humanities

\section{LEGAL REGULATION OF OFFSHORE BANKS IN SOME JURISDICTIONS}

Summary:

The paper presents a comparative legal analysis of the activities of bank credit organizations in different jurisdictions. The author reveals some aspects of legal regulation of offshore banks functioning in countries like Panama, Switzerland and Monaco. In particular, it describes the control and supervisory powers of the state in relation to offshore banks, summarizes the features of taxation and licensing of their activities. In addition, the author provides specific indicators on the taxation of the studied offshore jurisdictions. Banking is considered through tax relations. Various points of view of Russian scientists on this issue are presented, including their economic rather than legal orientation, which confirms the relevance and timeliness of the study. The conclusion about the position of offshore banks in Panama, Switzerland and Monaco is formulated.

Современная мировая экономика характеризуется высоким уровнем глобализации. Неотъемлемой частью экономики являются офшорные юрисдикции, которые предоставляют свободный доступ на международный рынок. Мировой экономический кризис 2007-2009 гг. только усугубил проблематику по оптимизации налогов и повысил объемы использования офшорных зон. В настоящее время экономическая политика многих крупных государств также движется в сторону увеличения размеров налогов. Все это создает предпосылки для возрастания привлекательности и активности фрунцциониования офшорных юрисдикций.

Как правило, категория «офшор» связывается с легализацией денежных средств, полученных преступным путем или с помощью иной незаконной деятельности. Однако с этим нельзя согласиться, поскольку офшорная юрисдикция в определенной степени может также обеспечить защиту прав налогоплательщиков, в частности права на уменьшение размера налогов законным способом. Тем не менее понимание особенностей функционирования офшорных юрисдикций может стать мощным инструментом в руках государства, который способен обеспечить защиту от использования офшоров в преступных целях. Таким образом, актуальность исследования института офшоров обусловлена возрастанием интереса к нему со стороны субъектов предпринимательства, необходимостью формирования странами оптимальной политики по отношению к офшорам с целью сохранить баланс между интересами налогоплательщиков и государства.

Большинство соответствующих комплексных исследований, посвященных теме офшорных юрисдикций, проводятся с позиции экономической науки (О.С. Живихина [1], Р.Б. Кутаков [2], С.А. Басова [3] и др.). Авторы анализируют основные понятия, структуру офшорных отношений, историю развития офшорной деятельности и иные теоретические аспекты. Среди практических результатов необходимо отметить фрормулирование ключевых концепций регулирования движения офшорного капитала в России. Правовые аспекты функционирования офшорных зон и работы офшшорных компаний отражены в диссертационном исследовании Е.Е. Шатиловой [4] и 
научных публикациях В.В. Павлова [5], А.Г. Цалоевой [6], Н.Г. Дорониной [7]. Большинство ученых указывают на необходимость усиления государственного контроля за деятельностью офшорных организаций и вносят соответствующие предложения (например, создание для этих целей специального органа, внесение изменений в гражданское и налоговое законодательство).

В целом можно говорить о недостаточной теоретической базе для проведения разработок по данной теме, в связи с чем мы осуществляем преимущественно анализ нормативных правовых актов некоторых зарубежных стран. Такое сравнительно-правовое сопоставление имеет целью установление особенностей правового регулирования деятельности офшорных банков в различных офшшорных юрисдикциях. Подобные банки стали предметом настоящего исследования в связи с тем, что являются одним из основных видов офшорных фирм.

Деятельность офшорных банков базируется на нахождении в офшорных финансовых центрах и специализированных зонах, которые представляют собой определенные государства (или его часть) с системой местного корпоративного законодательства, позволяющего регистрацию и функционирование офшорных компаний. Деятельность последних основана на извлечении прибыли из источников, расположенных вне страны или территории их регистрации. Категория «офршор» (англ. offshore - 'вне границ') включает организации, получившие регистрацию в юрисдикции государства при льготных условиях налогообложения и при отсутствии валютного контроля, а офшорные зоны являются особым классом свободных экономических зон.

Для проведения аналитического обзора деятельности офшорных банков и их правового регулирования мы обратились к приказу Министерства финансов России от 13 ноября 2007 г. № 108н в редакции от 2 ноября 2017 г., в рамках которого определяются территории и государства, устанавливающие льготный налоговый режим. Путем правового анализа рассмотрена деятельность нескольких офшорных центров.

Республика Панама. Страна является одним из офшорных финансовых центров с предоставлением услуг по регистрации офшорных организаций. В настоящее время, согласно данным надзорного органа за деятельностью банков - Superintendency of Banks of Panama, в стране действуют 26 офшорных банков (имеющих лицензию на осуществление международных операций, обладающих правом принимать депозиты лишь от лиц или организаций, расположенных за пределами государства регистрации) [8].

Правовое регулирование деятельности банков, в том числе офшорных, в Панаме осуществляется по нормам банковского права, которое основывается на декрет-законе № 9 от 26 февраля 1998 г. с последними изменениями от 22 февраля 2008 г. [9]. Данный документ формулирует практику надзора в отношении банков. Согласно ст. 1 закона № 9, его положения применяются к следующим организациям: банкам или любому лицу, занимающемуся банковской деятельностью в Республике Панама или из нее; банковским группам, как они определены в настоящем законе и нормативных актах, изданных для его реализации; представительствам; небанковским или нефинансовым филиалам. Согласно ст. 41 закона № 9, устанавливается требование по лицензированию банковской деятельности, никто не может заниматься банковским бизнесом в Панаме без соответствующей лицензии, представленной тремя следующими видами.

1. Генеральная банковская лицензия (General License Banks) позволяет лицензиату заниматься банковской деятельностью в Республике Панама.

2. Международная банковская лицензия (International License Banks), или лицензия офшорных банков, дает возможность осуществлять банковскую деятельность из офиса, расположенного в Панаме, совершая при этом сделки за рубежом. Имеющие лицензию на осуществление международных операций банки (в том числе офшорные) могут принимать депозиты лишь от лиц или организаций, находящихся за рубежом.

3. Представительская лицензия (Representative Offices) позволяет лицензированным иностранным банкам открывать представительство в Республике Панама. Один из офшорных банков - Banvivienda - в настоящее время является универсальным банком, который предоставляет полный спектр продуктов и услуг для осуществления персональных, коммерческих, специализированных и сельскохозяйственных банковских операций [10].

Надзорную деятельность осуществляет Управление банками Панамы (Superintendency of Banks of Panama) - орган надзора и регулирования банковского сектора индустрии финансовых услуг государства. Регламентация надзорной деятельности рассматриваемой организации устанавливается в разделе II закона № 9, исходя из содержания которого Управление банками имеет следующие контрольно-надзорные полномочия.

1. Обеспечение возможности поддержания банками достаточных коэффициентов ликвидности и платежеспособности для выполнения своих обязательств, а также адекватных процедур, позволяющих осуществлять контроль за их национальной и международной деятельностью в 
тесном сотрудничестве с иностранными надзорными органами, если это необходимо; разработка нормативной базы для банковской системы.

2. Наложение предусмотренных законодательством санкций на стороны, виновные в ведении банковской деятельности без надлежащего разрешения. Санкции определяются в денежном выражении в национальной валюте, а также в иных мерах, в том числе лишении лицензии.

3. Осуществление таких функций, которые могут быть возложены на него настоящим законом или другими нормативными актами.

В отношении налогообложения действуют достаточно простые правила - в Панаме принята территориальная налоговая система, в соответствии с которой резиденты и нерезиденты облагаются налогом только на доходы из панамских источников. Доход, который не возникает или не является производным от Панамы, не облагается здесь налогом. Это означает, что получение прибыли банками от зарубежных источников не облагается налогами. По данным обзора интернет-портала Deloitte [11], в 2018 г. налогообложение банков в Панаме характеризовалось следующими показателями.

1. Налог на прибыль: оценивается по максимальной фиксированной ставке $25,00 \%$ на чистый налогооблагаемый доход или ставке 1,17 \% на валовой налогооблагаемый доход.

2. Дивиденды: компании, имеющие «уведомление об операциях» или иным образом ведущие бизнес, должны удерживать налог в размере $10 \%$ на дивиденды, распределенные из внутренней прибыли (20\% по акциям на предъявителя), $5 \%$ - распределенные из иностранных источников или экспортной прибыли.

3. Роялти (платежи по вкладам и иные платежи банков нерезидентам): выплачиваются нерезиденту, облагаются подоходным налогом в размере 12,5 \%, если платеж приносит пользу резиденту Панамы или если расходы в Панаме считаются подлежащими вычету.

Проанализированные положения законодательства Панамы и практика их реализации показывают, что республика позволяет вести офшорную деятельность без уплаты налогов за работу за территорией государства. В стране установлена система контроля и надзора за банковской деятельностью при высоком уровне соблюдения конфиденциальности и банковской тайны, ограничении обмена информацией.

Швейцария. Банковская система страны является одной из лучших и самых надежных для инвестиций и вкладов в мире. Сегодня офршорный характер деятельности здесь следует считать условным, поскольку структура находится под жестким банковским контролем. Один из первых офшорных банков Швейцарии - HSBC Private Bank in Switzerland [12].

Правовое регулирование основывается на Федеральном законе Швейцарии о банках и сберегательных банках от 8 ноября 1934 г. (Swiss Federal Act on Banks and Savings Banks) в редакции от 1 января 2019 г. [13]. Согласно разд. 2 ст. 3 указанного документа, для банковской деятельности необходимо получение лицензии FINMA - Швейцарского органа по надзору за финансовым рынком, представляющего собой публично-правовое учреждение с собственной правосубъектностью и официальным представительством в Берне.

Контрольно-надзорные полномочия государства устанавливаются на основании Федерального закона о надзоре за финансовым рынком Швейцарии от 22 июля 2007 г. в редакции от 1 января 2019 г. Согласно ст. 5 рассматриваемого документа, органом, осуществляющим надзор за финансовым рынком, является FINMA. Надзорный закон определяет общие положения по контролю: нормативное регулирование и разъяснение законодательства.

На основании разд. 10 ст. 23 Федерального банковского закона Швейцарии FINMA может проводить прямые аудиторские проверки банков, банковских групп и фринансовых конгломератов, если это необходимо, учитывая экономическую важность и сложность вопросов, которые нужно выяснить, или внутренние модели. Проверки проводятся в любое время. В их рамках осуществляется анализ показателей ликвидности, контрольный орган имеет право принимать участие в процедуре прекращения деятельности банка.

Оценить категории обслуживаемых лиц возможно посредством анализа одного из самых больших офшорных банков мира - HSBC Private Bank in Switzerland. Организация обслуживает физических и юридических лиц в рамках проведения банковских операций, организации депозитов. Наибольшее внимание уделяется фризическим лицам (предлагаются вклады, управление капиталом и иные депозитные продукты) [14].

Далее рассмотрены особенности налогообложения банков в Швейцарии (таблица 1). Здесь зарегистрирован самый низкий налог на прибыль, отсутствуют налоги при получении дохода от деятельности за пределами страны. Несмотря на известный статус надежного офшора, система жестко контролируется государством, вкладчику-инвестору могут отказать в обслуживании в результате непредоставления необходимой информации об источниках доходов. Данные меры 
превращают Швейцарию в надежного хранителя законных доходов, но не делают из нее офшорную территорию.

Таблица 1 - Налогообложение в Швейцарии

\begin{tabular}{|l|l|}
\hline \multicolumn{1}{|c|}{ Налог } & \multicolumn{1}{|c|}{ Описание } \\
\hline Налог на прибыль & $8,5 \%$ \\
\hline НдС & $\begin{array}{l}\text { Не взимается с услуг, оказанных за пределами страны, или } \\
\text { товаров, экспортируемых за ее пределы }\end{array}$ \\
\hline Налог с дивидендного дохода & 0 \% или частичное освобождение \\
\hline Налог с иностранного дохода & Отсутствует \\
\hline
\end{tabular}

Монако. Государство насчитывает около 79 банков и финансовых учреждений более чем с 300000 учетными записями (при этом здесь проживают 7600 граждан и зарегистрированы еще 28000 иностранных жителей). Примерно 85 \% клиентов банков являются нерезидентами. Банковский оборот составляет более 2 млрд евро, а активы под управлением местных кредитных учреждений превышают 78 млрд евро.

По операциям за пределами Монако налоги не уплачиваются, однако любой бизнес с более 25,00 \% оборота за пределами Монако облагается налогом в размере 33,33 \% с прибыли. Органом контроля финансовых и банковских институтов с 1945 г. является организация French Commission bancaire (FCB) в связи с заключением соглашения между Монако и Францией. Монако предоставляет качественные услуги и гарантирует отсутствие налогообложения нерезидентов, имеющих счета в банках Монако, но не приветствует офшорную деятельность.

Исследование позволяет сделать вывод о том, что правовое регулирование деятельности офшорных банков в Панаме, Швейцарии и Монако представляет собой сложную конструкцию правового подчинения и контроля местным законодательством, основанным также на международных договорах и соглашениях, соблюдение которых создает гармоничные условия деятельности в рамках законности и правопорядка. Таким образом, названные государства фрормируют возможности для реализации предпринимателями права на уменьшение размеров налогов законным путем, защиту активов, обеспечивают им комфортное осуществление внешнеэкономической деятельности и различными правовыми средствами пытаются не допустить отмывания денежных средств и иной противоправной деятельности путем использования офшорных банков своей юрисдикции.

Российская Федерация избрала путь, ориентированный на деофшоризацию экономики, что подтверждает, в частности, разработанная экспертным управлением президента РФ программа деофшоризации отечественной экономики «Повышение привлекательности российской юрисдикции для ведения бизнеса». Следовательно, проанализированный опыт современных мировых структур в финансовом секторе, использующих офшорные юрисдикции, может быть воспринят нашим государством.

\section{Ссылки:}

1. Живихина О.С. Регулирование офшорного бизнеса в целях совершенствования налогового планирования : дис. ... канд. юрид. наук. М., 2013. 143 с.

2. Кутаков Р.Б. Офшорные территории в мировой и российской практике : дис. ... канд. юрид. наук. М., 2008. 111 с.

3. Басова С.А. Офшоризация как закономерность глобализации и ее воздействие на экономику России : дис. ... канд. экон. наук. Кемерово, 2006. 184 с.

4. Шатилова Е.Е. Правовое регулирование использования офшоров в деятельности российских предпринимателей : дис. ... канд. юрид. наук. М., 2007. 187 с.

5. Павлов В.В. Офшорная деятельность: вопросы правовой регламентации // Журнал российского права. 2011. № 5 (173). C. 31-39.

6. ЦЦалоева А.Г. Офшорный бизнес в Российской Федерации: анализ правового регулирования // Современная юриспруденция: актуальные вопросы, достижения и инновации : сборник статей II Международной научно-практической конференции. Пенза, 2017. С. 104-106.

7. Доронина Н.Г. Правовое регулирование офшшорных зон по российскому законодательству // Журнал российского права. 2012. № 6 (186). С. 107-111.

8. International License [Электронный ресурc] // Superintendency of Banks of Panama. URL: https://www.superbancos.gob.pa/en/gen-info-banks/international-license (дата обращения: 07.10.2019).

9. Executive Decree no. 529 of Febr. 26, 1998 [Электронный ресурc] : modified by Decree Law 2 of Febr. 22, 2008 // lbid. URL: https://www.superbancos.gob.pa/superbancos/documents/laws_regulations/laws/blaw.pdf (дата обращения: 07.10.2019).

10. Historical Overview Banvivienda [Электронный ресурc] // Banvivienda. URL: https://www.banvivienda.com/en/historicaloverview (дата обращения: 07.10.2019).

11. International Tax Panama Highlights 2018 [Электронный ресурc] // Deloitte Touche Tohmatsu Limited. 2018. URL: https://www2.deloitte.com/content/dam/Deloitte/global/Documents/Tax/dttl-tax-panamahighlights-2018.pdf?nc=1 (дата обращения: 01.03.2019). 
12. Transaction Banking. Deposit Accounts [Электронный ресурc] // HSBC Private Bank. 2019. URL: https://www.hsbcprivatebank.com/en/bank/transactional-banking (дата обращения: 07.10.2019).

13. Swiss Federal Act on Banks and Savings Banks [Электронный ресурс] : of Nov. 8, 1934 : version as at 1 Jan. 2019 // KPMG. URL: https://assets.kpmg/content/dam/kpmg/ch/pdf/ch-banking-act-en.pdf (дата обращения: 07.10.2019).

14. Transaction Banking ...

\section{References:}

Basova, SA 2006, Offshorization as a Pattern of Globalization and Its Impact on the Russian Economy, PhD thesis, Kemerovo, 184 p., (in Russian).

Doronina, NG 2012, 'Legal Regulation of Offshore Zones under Russian Law', Zhurnal rossijskogo prava, no. 6 (186), pp. 107-111, (in Russian).

Kutakov, RB 2008, Offshore Territories in World and Russian Practice, PhD thesis, Moscow, 111 p., (in Russian).

Pavlov, VV 2011, 'Offshore Activities: Legal Issues', Zhurnal rossijskogo prava, no. 5 (173), pp. 31-39, (in Russian).

Shatilova, EE 2007, Legal Regulation of the Use of Offshore in the Activities of Russian Entrepreneurs, PhD thesis, Moscow, 187 p., (in Russian).

Tsaloeva, AG 2017, 'Offshore Business in the Russian Federation: Analysis of Legal Regulation', Sovremennaya yurisprudentsial aktualnye voprosy, dostizhenia i innovatsii: sbornik statei II Mezhdunarodnoi nauchno-prakticheskoi konferentsii, Penza, pp. 104-106, (in Russian).

Zhivikhina, OS 2013, Offshore Business Regulation to Improve Tax Planning, PhD thesis, Moscow, 143 p., (in Russian).

Редактор: Тюлюкова Мария Олеговна Переводчик: Ездина София Александровна 